\title{
ISTRAŽIVANJE ZADOVOLJSTVA KORISNIKA MREŽNOM USLUGOM PITAJTE KNJIŽNIČARA - TEMATSKO PRETRĂ̌IVANJE NACIONALNE I SVEUČILIŠNE KNJIŽNICE U ZAGREBU TIJEKOM PANDEMIJE KORONAVIRUSA
}

\author{
A SURVEY OF USER SATISFACTION \\ WITH THE NATIONAL AND UNIVERSITY LIBRARY IN \\ ZAGREB ONLINE SERVICE ASK A LIBRARIAN - THEMATIC \\ SEARCHES DURING THE COVID-19 LOCKDOWN
}

Ivona Milovanović

Nacionalna i sveučilišna knjižnica u Zagrebu imilovanovic@nsk.hr

Ivana Kežić Pucketić

Nacionalna i sveučilišna knjižnica u Zagrebu ivana.kezic@nsk.hr

Dolores Mumelaš

Nacionalna i sveučilišna knjižnica u Zagrebu dmumelas@nsk.hr

UDK / UDC [027.54:004]: 616.2044.372(497.5 Zagreb)

Stručni rad / Professional paper

Primljeno / Received: 15. 12. 2020.

Prihvaćeno / Accepted: 2. 3. 2021.

\section{Sažetak}

Cilj. Cilj je rada predstaviti rezultate istraživanja o iskustvu i zadovoljstvu korisnika mrežnom uslugom Pitajte knjižničara - tematsko pretraživanje Nacionalne i sveučilišne knjižnice u Zagrebu tijekom fizičkog zatvaranja Knjižnice i uspostave rada djelatnika od kuće, kada su na snazi bile mjere izolacije radi suzbijanja širenja bolesti COVID-19.

Vjesnik bibliotekara Hrvatske 64, 1(2021), 279-301 ISSN 0507-1925 
Pristup/metodologija/dizajn. U istraživanju korisnika usluge korištena je metoda ankete, za čiju se provedbu koristio mrežni anketni upitnik sastavljen od 10 pitanja. Prethodno je napravljena analiza podataka iz mrežne aplikacije Pitajte knjižničara - tematsko pretraživanje iz koje su prikupljeni podaci o korisnicima i zahtjevima za tematsko pretraživanje tijekom izvanrednih uvjeta rada Knjižnice te je poziv za ispunjavanje anketnog upitnika poslan na adrese $e$-pošte korisnika usluge u tom razdoblju.

Rezultati. Rezultati istraživanja pokazali su kako je na odluku o korištenju usluge tematskog pretraživanja tijekom izolacije kod najvećeg broja ispitanika utjecalo dosadašnje pozitivno iskustvo, a zatim preporuka druge osobe. Utvrđeno je zadovoljstvo korisnika kvalitetom usluge, kao i opsegom preporučene literature, dostupnošću sadržaja, brzinom odgovora, pružanjem dodatnih referalnih i drugih informacija te komunikacijom s knjižničarom. Pokazalo se i da je velik broj ispitanika naknadno samostalno pretraživao $e$-izvore, što potvrđuje napore i trud djelatnika da, osim pružanja relevantnih informacija u obliku preporučene literature na traženu temu, ujedno educiraju korisnike o dostupnim mrežnim izvorima informacija.

Praktična primjena. Dobivanjem povratnih informacija od korisnika usluge omogućeno je vrednovanje rada knjižničara - predmetnih stručnjaka zaduženih za pružanje usluge, kojima će rezultati istraživanja poslužiti u organizaciji i usavršavanju načina rada u budućnosti.

Originalnost/vrijednost. Rezultati istraživanja poslužit će za daljnji razvoj i unaprjeđivanje usluge Pitajte knjižničara - tematsko pretraživanje.

Ključne riječi: istraživanje korisnika, izvanredni uvjeti rada, Nacionalna i sveučilišna knjižnica u Zagrebu, pandemija koronavirusa, tematsko pretraživanje.

\section{Abstract}

Purpose. The aim of the paper is to present the results of a research into the experience and satisfaction of users with the online service Ask a Librarian - a thematic search of the National and University Library in Zagreb during lockdown and the establishment of work from home, when isolation measures were in place to prevent the spread of COVID-19.

Approach/methodology/design. The survey method was used in the research of the service users, and a 10-question online questionnaire was created for this purpose. Before the survey, the analysis of the data from the Ask a Librarian - thematic searches online application was conducted. The data on the users and requests for the thematic searches were collected during the lockdown period in which the library was working in exceptional circumstances, and the survey invitation was sent to the e-mail addresses of the users of the service in that period. 
Results. The results of the survey have shown that the users' decision to use a thematic search service during the period of isolation was influenced by a previous positive experience with this service, or another person's recommendation. It was found that users were satisfied with the quality of the service, as well as with the amount of literature recommended, the availability of content, the promptness of responses, the provision of additional references and other information, and communication with the librarians. It was shown that a large number of respondents also subsequently independently searched the e-resources, thereby confirming the value of the effort made by librarians to educate users about the available online information sources, and not only provide the relevant information on a particular topic in the form of recommended literature.

Practical application. Obtaining feedback from the service users made possible the evaluation of the work of librarians, the library's subject specialists who are responsible for providing this service, and the research results will serve them in the organization and improvement of their work in the future.

Originality/value. The results of the research will be used for the further development and upgrading of the Ask the Librarian - a thematic search online service.

Keywords: coronavirus pandemic, exceptional working conditions, National and University Library in Zagreb, service user research, thematic search

\section{Uvod}

U skladu s mjerama suzbijanja širenja bolesti COVID-19, a prema preporukama Nacionalnog kriznog stožera, Ministarstva kulture Republike Hrvatske i Ministarstva znanosti i obrazovanja Republike Hrvatske, Nacionalna i sveučilišna knjižnica u Zagrebu bila je prvo u potpunosti, a zatim djelomično zatvorena za korisnike od 19. ožujka do 25. svibnja 2020., ${ }^{1}$ a njezini djelatnici bili su raspoređeni na rad od kuće od 20. ožujka do 8 . svibnja. ${ }^{2} \mathrm{U}$ tom je razdoblju bilo potrebno u potpunosti ili djelomično reorganizirati rad djelatnika

\footnotetext{
1 Nacionalna i sveučilišna knjižnica u Zagrebu. Obavijest korisnicima o zatvaranju Knjižnice u skladu s mjerama suzbijanja širenja bolesti COVID-19. 19. ožujka 2020. [citirano 2021-0212]. Dostupno na: https://www.nsk.hr/obavijest-korisnicima-o-zatvaranju-knjiznice-u-skladu-s-mjerama-suzbijanja-sirenja-bolesti-covid-19-19-ozujka-2020-7-30/; Nacionalna i sveučilišna knjižnica u Zagrebu. Obavijest o otvaranju čitaonica Knjižnice prema ograničenom sustavu rada. 21. svibnja 2020. [citirano:2021-03-02]. Dostupno na: https://www.nsk.hr/obavijest-o-otvaranju-citaonica-knjiznice-prema-ogranicenom-sustavu-rada-21-svibnja-2020/.

2 Nacionalna i sveučilišna knjižnica u Zagrebu. Odluka o organizaciji rada, rasporedu rada i radnog vremena tijekom trajanja epidemije bolesti COVID 19 uzrokovane virusom SARSCoV-2. 20. ožujka 2020. [citirano 2021-02-12]. Dostupno na: https://www.nsk.hr/wp-content/ uploads/2020/04/Odluka-o-organizaciji-rada-COVID-19.pdf.
} 
i poslovanje Knjižnice, a posebna se pozornost usmjerila na kontinuirano i učinkovito pružanje usluga na daljinu. ${ }^{3}$ Mnoge su usluge i ranije bile dostupne u virtualnom okruženju, a među njima i informacijska usluga Pitajte knjižničara - tematsko pretraživanje koju provode diplomirani knjižničari - predmetni stručnjaci Odjela korisničke službe. Za razliku od redovnog načina rada, u kojem virtualna usluga supostoji uz uslugu u tradicionalnom smislu te korisnici imaju mogućnost osobnog dolaska u prostor Knjižnice kako bi na licu mjesta od predmetnog stručnjaka dobili popis preporučene literature prema traženoj temi i koristili građu iz fonda Knjižnice, u novonastaloj situaciji komunikacija s korisnicima bila je svedena na e-poštu. Zahvaljujući mrežnoj aplikaciji u kojoj korisnici mogu poslati svoje zahtjeve za tematsko pretraživanje, popunjavajući pritom mrežni obrazac u kojem pobliže opisuju svoju temu i područje interesa, navode u koju svrhu traže pretraživanje te ostale podatke koji knjižničarima služe kao svojevrsna zamjena za uobičajeni informacijski intervju, predmetni stručnjaci mogli su nastaviti s redovnim radom i od kuće. Budući da najveći broj korisnika usluge tematskog pretraživanja čine studenti i znanstveno-nastavno osoblje, a da su se i nastava i rad akademske i znanstvene zajednice $u$ to vrijeme također provodili u virtualnom okruženju, broj zahtjeva za tematsko pretraživanje u navedenom razdoblju nije bio manji nego u redovnim okolnostima. Od 20. ožujka do 8. svibnja pristiglo je ukupno 289 zahtjeva, a najveći izazov za predmetne stručnjake predstavljali su zahtjevi za što više mrežno dostupnih sadržaja, $s$ obzirom na to da do tiskane građe nisu mogli doći, zbog čega se pretraživanju dostupnih izvora u potrazi za relevantnom literaturom i kvalitetnim sadržajima u otvorenom pristupu trebala posvetiti posebna pozornost. Suočeni s ograničenim resursima i nemogućnosti pristupa građi, izvorima i materijalima dostupnima na radnom mjestu u Knjižnici, kao i manjkom izvora za pojedina područja i polja znanosti čija temeljna literatura još uvijek počiva na tiskanim izvorima, bilo je zaista potrebno „u hodu" nadograđivati i usavršavati dosad stečene vještine i znanja kako bi na najbolji mogući način odgovorili na korisničke upite i zahtjeve.

U ovom će se radu naglasak staviti na informacijsko-referalne usluge, posebno Pitajte knjižničara - tematsko pretraživanje i načine pružanja relevantnih informacija i sadržaja, bilo u fizičkom, bilo u virtualnom okruženju te naposljetku prikazati rezultati istraživanja zadovoljstva korisnika uslugom tijekom izvanrednih uvjeta rada Knjižnice, provedenog u svrhu vrednovanja pružene usluge u novonastalim epidemiološkim uvjetima.

\footnotetext{
Nacionalna i sveučilišna knjižnica u Zagrebu. Podsjetnik o trenutačno dostupnim uslugama Nacionalne i sveučilišne knjižnice u Zagrebu. 25.ožujka 2020. [citirano 2021-02-12]. Dostupno na: https://www.nsk.hr/podsjetnik-o-trenutno-dostupnim-uslugama-nacionalne-i-sveucilisne-knjiznice-u-zagrebu/.
} 


\section{Informacijsko-referalne usluge u mrežnom okruženju}

Informacijsko-referalne usluge podrazumijevaju organizaciju i provođenje različitih usluga usmjerenih na korisnika, u nastojanju da se što bolje i preciznije odgovori na njegove informacijske potrebe, odnosno na one oblike usluga koji se u najširem smislu odnose na posredništvo knjižničara u traženju i pronalaženju informacija. ${ }^{4}$ Iako se navedene usluge oduvijek smatraju temeljnim zadaćama knjižnica, potreba za organizacijom posebnih službi, odjela i usluga u svrhu posredovanja između korisnika i znanstvenih informacija i izvora te općenito fonda knjižnice pojavila se usporedno s razvojem znanosti i ekspanzijom znanstvenih informacija još u 19. stoljeću, kada je, u nastojanju da se odgovori na konkretnu potrebu korisnika, fokus stavljen na osiguravanje pristupa relevantnim izvorima, bez obzira na medij. ${ }^{5}$ Razvoj tehnologije i sve veća raširenost u primjeni računalne i informacijsko-komunikacijske tehnologije uvjetovali su sredinom 20. stoljeća i razvoj usluga u mrežnom okruženju i promjenu u načinu komunikacije između korisnika i knjižničara, čime se tradicionalni način pružanja usluge utemeljen na izravnom (fizičkom) kontaktu preselio u virtualni svijet, a usluge su se počele pružati i na daljinu - e-poštom, mrežnim programima i obrascima, chatovima i slično. ${ }^{6}$ Iako su pojedini autori smatrali kako primjena tehnologije i uspostava virtualnih usluga tek nadopunjuju tradicionalne usluge, ali ih neće zamijeniti jer se ne mogu mjeriti s učinkovitom praksom i izravnim, fizičkim kontaktom korisnika i knjižničara, ${ }^{7}$ knjižnice su bilježile pad dolazaka i upita korisnika koji su se sve više okretali traženju informacija na internetu, što je ukazalo na potrebu da uz pomoć dostupne tehnologije razvijaju svoje usluge u mrežnom okruženju, pristupačne većem broju korisnika ${ }^{8}$ te tako prošire svoje djelovanje i osiguraju dostupnost usluga i korisnicima koji fizički ne posjećuju knjižnice. ${ }^{9}$

Iz dostupne literature na prijelazu iz 20. u 21. stoljeće može se zaključiti kako su razvoj tehnologije te uspostava digitalnih knjižnica i mrežnih usluga donijeli velike promjene u knjižničarstvu u načinu odgovaranja na nove i drugačije informacijske potrebe korisnika. Objavljeni su mnogobrojni radovi koji su se bavili

\footnotetext{
Usp. Bosančić B. Online referentne usluge: pregled razvoja u teoriji i praksi. // Vjesnik bibliotekara Hrvatske 53, 1(2010), str. 66. [citirano 2020-12-08]. Dostupno i na: https://www.hkdrustvo.hr/vjesnik-bibliotekara-hrvatske/index.php/vbh/article/view/446.

${ }^{5}$ Usp. Sečić, D. Informacijska služba u knjižnici. Lokve: Benja, 1995. Str. 15-16.

6 Usp. Bosančić B. Nav. dj., str. 66.

7 Usp. Lauer, J. D. ; S. McKenzie. Bad moon rising: a candid examination of digital reference and what it means to the profession. // Digital reference services / ed. B. Katz. New York: The Haworth Information Press, 2003. Str. 55.

8 Usp. Bakker, T. Virtual reference services: connecting users with experts and supporting the development of skills. // LIBER Quarterly 12, 2-3(2002), str. 124-125. DOI: http://doi.org/10.18352/ lq.7676.

9 Usp. Breeding, M. Providing virtual reference service. // Information Today 18, 4(2001), str. $42-43$
} 
teorijskim i praktičnim pitanjima te definiranjem novih usluga na daljinu, uključujući uspostavu i tehničke aspekte njihova razvoja, upravljanja i vrednovanja, ${ }^{10}$ potrebom za stalnim razvijanjem novih oblika usluga i inovativnim rješenjima $u$ skladu s brzim promjenama u diseminaciji informacija i korištenjem novih tehnologija, ${ }^{11}$ kao i središnjom ulogom knjižničara kao posrednika između korisnika i njihovih informacijskih potreba, čiji poslovi u mrežnom okruženju imaju i doda$\mathrm{nu}$ vrijednost jer istovremeno usmjeravaju korisnike na relevantne informacije i izvore i sudjeluju u edukaciji korisnika, izravno ili pisanjem raznih uputa i vodiča. ${ }^{12}$ Pružanje usluga u mrežnom okruženju zahtijeva od knjižničara prilagodbu na korištenje novih tehnologija, kao i stjecanje novih kompetencija i vještina u komunikaciji s korisnicima. ${ }^{13}$ Porastom broja mrežnih informacijskih usluga, kao i broja virtualnih korisnika, sve se više pozornosti usmjerava na vrednovanje, odnosno mjerenje percepcije i razine zadovoljstva korisnika pojedinim uslugama, za što su prikladna anketna istraživanja. ${ }^{14} \mathrm{Na}$ taj je način omogućeno dobivanje povratnih informacija u svrhu analiziranja, poboljšavanja i proširivanja postojećih usluga te uključivanje mišljenja korisnika u procese planiranja i razvijanja novih, inovativnih oblika usluga, ${ }^{15}$ kao i mjerenje kvalitete usluge radi razumijevanja ponašanja korisnika i stvaranja preduvjeta za povećanje njihova zadovoljstva uslugom. ${ }^{16}$ Osim potpore korisnicima kojima su mrežni alati i izvori nepoznati ili nedovoljni kao odgovor na njihove informacijske potrebe, ističe se kako mrežne usluge pružaju knjižničarima mogućnost brze povratne informacije od korisnika koje im služe za izgradnju zbirki, kako bi mogli bolje prilagoditi svoje resurse i povećati svoja ulaganja u stavljanju relevantnog i korisnog sadržaja korisnicima na raspolaganje. ${ }^{17}$

10 Vidjeti npr. Coffman, S. Going live: starting and running a virtual reference service. Chicago: American Library Association, 2003.

11 Vidi npr. New directions in reference / ed. Byron Andreson and Paul T. Webb. Binghamton: The Haworth Information Press, 2006.

12 Usp. Sloan, B. Service perspectives for the digital library remote reference services. // Library Trends 47, 1 (1998), str. 123-124. [citirano 2020-02-12]. Dostupno na: http://hdl.handle. net $/ 2142 / 8200$.

13 Usp. Sanders, L. The reality of reference: responsibilities and competencies for current reference librarians. // Public Services Quarterly 8, 2(2012), str. 127. DOI: https://doi.org/10.1080/15 228959.2012.662074.

14 Usp. VandeCreek, L. M. E-mail reference evaluation: using the results of a satisfaction survey. // The Reference Librarian 45, 93(2006), str. 100-101. DOI: https://doi.org/10.1300/ J120v45n93_08.

15 Isto, str. 106.

16 Usp. Gómez-Cruz, M. E. Electronic reference services: a quality and satisfaction evaluation. // Reference Services Review 47, 2(2019), str. 130. DOI: https://doi.org/10.1108/RSR-07-20180057.

17 Usp. Oluwabiyi, M. O. Digital reference services: an overview. // Information Impact: Journal of Information and Knowledge Management 8, 1(2017), str. 68. DOI: https://dx.doi.org/10.4314/ iijikm.v8i1.8. 


\section{Informacijske usluge knjižnica tijekom pandemije koronavirusa}

Početkom globalne pandemije koronavirusa knjižnice su svoje usluge u velikoj mjeri ostvarivale oslanjajući se na elektroničke oblike poslovanja, služeći se pritom svim raspoloživim tehnološkim alatima, primjerice razvojem učinkovitih softvera, aplikacija i sučelja, kako bi što potpunije odgovorile na potrebe korisnika. Digitalno su okruženje knjižnice iskoristile kako bi promovirale svoje usluge na daljinu, izrađivale objedinjene popise digitalnih knjižnica, baza $e$-izvora i najčešće korištenih aplikacija za provođenje virtualnih sadržaja i webinara te digitalizirale građu. ${ }^{18}$ Brojne knjižnice razvile su smjernice i vodiče za knjižničare i korisnike te upućivale korisnike na izdavače koji su omogućili pristup mrežnim sadržajima na određeno vrijeme. ${ }^{19}$ U Hrvatskoj je Komisija za informacijske tehnologije Hrvatskog knjižničarskog društva uspostavila interaktivnu mrežnu tablicu Knjižnične usluge na daljinu ${ }^{20}$ kako bi na jednom mjestu okupila sve mrežno dostupne usluge hrvatskih knjižnica, omogućujući knjižnicama samostalno uključivanje i dodavanje sadržaja.

U inozemnoj se literaturi mogu pronaći objavljena istraživanja knjižnica o vrednovanju rada i pružanju usluga u novonastalim epidemiološkim uvjetima, provedena u svrhu oblikovanja i bolje prilagodbe novim načinima rada. Knjižnice Sveučilišta Toronto provele su istraživanje ${ }^{21}$ o provođenju svojih usluga tijekom lockdowna od ožujka do svibnja 2020. godine. Rezultati su pokazali kako je velik broj korisnika koristio informacijsko-referalnu uslugu Ask Chat with a Librarian, a zabilježeno je da se koristila $50 \%$ više nego prije lockdowna, te se zaključuje kako su knjižnice pravovremeno i valjano odgovorile na upite korisnika i svojim djelovanjem nastavile biti potpora akademskoj zajednici. Opširno istraživanje o radu knjižnica tijekom pandemije provedeno je i u Kini ${ }^{22}$ u 137 kineskih visokoškolskih knjižnica, gdje su između ostaloga prikupljeni i podaci o uslugama koje su knjižnice tada pružale, većinom na društvenoj mreži WeChat koja služi kao kanal za pružanje informacijsko-referalnih usluga te tzv. mikro-blogova. Pokazalo se da

18 Usp. Asif, M.; K. K. Singh. Trends, opportunities and scope of libraries during Covid-19 pandemic. // IP Indian Journal of Library Science and Information Technology 5, 1(2020), str. 27. DOI: https://10.18231/j.ijlsit.2020.005.

19 Usp. Oyelude, A. Libraries, librarians, archives, museums and the COVID-19 pandemic. // Library Hi Tech News 9, 5/6(2020), str. 5. DOI: https://doi.org/10.1108/LHTN-05-2020-0049.

20 Komisija za informacijske tehnologije Hrvatskog knjižničarskog društva. Knjižnične usluge na daljinu - Remote Library Services. [citirano 2020-02-12]. Dostupno na: https://padlet.com/ hkdrustvo/knjiznicne_usluge_na_daljinu.

${ }_{21}$ Vidi Walsh, B.; H. Rana. Continuity of academic library services during the pandemic: The University of Toronto Libraries' response. // Journal of Scholarly Publishing 51, 4(2020), 237 245. DOI: https://doi.org/10.3138/jsp.51.4.04.

22 Vidi Guo, Y.; Z. Yang; Z. Yang; Y. Q. Liu; A. Bielefield; G. Tharp. The provision of patron services in Chinese academic libraries responding to the COVID-19 pandemic. // Library Hi Tech 38, 4(2020). Publication date: 21 July 2020. DOI: https://doi.org/10.1108/LHT-04-2020-0098. 
se korištenje društvenih mreža koje su i prije izvanrednih uvjeta rada bile u upotrebi pokazale iznimno korisnima i tijekom pandemije te su korisnici informacije i usluge radije tražili tako nego na mrežnim stranicama knjižnica. U Nigeriji ${ }^{23}$ je provedena komparativna analiza dviju visokoškolskih knjižnica o očekivanjima i zadovoljstvu korisnika radom, uslugama i izvorima knjižnica tijekom pandemije, a rezultati su između ostaloga pokazali kako korisnici obiju knjižnica imaju visoka očekivanja kada je riječ o pristupu mrežnim izvorima, informacijsko-referalnim uslugama i pružanju informacija $e$-poštom, kao i to da su bili prosječno zadovoljni knjižnicom te su ukazali na potrebu šire primjene informacijsko-komunikacijske tehnologije u pružanju usluga tijekom pandemije. Indijska knjižnica NIELIT Itanagar Library ${ }^{24}$ korisnicima je bila dostupna i preko mobilne aplikacije What$s A p p$ te je provela analizu poruka između korisnika i knjižničara, kao i istraživanje zadovoljstva korisnika. Istraživanje je pokazalo kako je takva usluga najvećem broju ispitanika odavala dojam da im je knjižnica „nadohvat ruke“, a iznimno su bili zadovoljni i pravodobnim pružanjem izvora i informacija, kao i kvalitetom primljenog sadržaja te dodatnim informacijama poput obavijesti o webinarima.

\section{Razvoj informacijsko-referalnih usluga Nacionalne i sveučilišne knjižnice u Zagrebu}

U Nacionalnoj u sveučilišnoj knjižnici u Zagrebu, Središnja informacijska služba uspostavljena je osamdesetih godina prošloga stoljeća, kada su korisnicima bile dostupne usluge verifikacije bibliografskih izvora i kataložnih informacija, pretraživanje stručnog kataloga te izrada bibliografskih popisa, a kasnije je bilo omogućeno i pretraživanje baza podataka na CD-ROM-u. Korisnicima su se pružali i savjeti o stručnoj i znanstvenoj literaturi, a upiti i zahtjevi korisnika najčešće su se zaprimali osobno, telefonom i pisanim kanalima komunikacije. ${ }^{25}$ Preseljenjem u novu zgradu i uvođenjem internetske veze omogućene su prve usluge na dalji-

\footnotetext{
23 Vidi Okonoko, V. N.; M. A. Abba, M. A.; A. E. Arinola, Users' expectation of library services and resources in the COVID 19 pandemic era: a comparative study of two academic libraries in nigeria. // Library Progress (International) 40, 2(2020), 236-246. DOI: http://dx.doi. org/10.5958/2320-317X.2020.00027.6.

24 Vidi Stephen, G. Chat metric for li(fe)brary at home whatsapp forum with user satisfaction of NIELIT - Itanagar Library, Arunachal Pradesh. // Library Philosophy and Practice (e-journal), 4818 (2021). [citirano 2020-02-10]. Dostupno na: https://digitalcommons.unl.edu/libphilprac/4818/.

25 Mihalić, M. Međunarodna kooperativna informacijska usluga QuestionPoint: pitajte knjižničara u Nacionalnoj i sveučilišnoj knjižnici u Zagrebu. // 2. međunarodna konferencija BAM 2008 Evropske smjernice za saradnju biblioteka, arhiva i muzeja: promocija usluga za korisnike: zbornik radova / ur. Lejla Kodrić, Nataša Milićević, Biserka Sabljaković. Sarajevo: Asocijacija informacijskih stručnjaka - bibliotekara, arhivista i muzeologa; Ekonomski fakultet, 2010. Str. 30-42. [citirano 2020-12-10]. Dostupno na: http://www.bam.ba/images/stories/Zbornici/bam zbornik_2008_online.pdf.
} 
nu, a razvojem informacijske tehnologije krajem 90-ih godina broj informacijskih upita korisnika znatno se povećao, u skladu s čime su se razvijale i postojeće i nove usluge u Odjelu korisničkih službi Knjižnice. Razvoj usluge na daljinu tekao je od zahtjeva u sklopu obrasca Pišite knjižnici pa do bibliografskih i kataložnih informacija izravno preko sučelja OPAC-a te naposljetku informacijske usluge na daljinu Pitajte knjižničara - QuestionPoint ${ }^{26}$ Mrežnu referentnu uslugu Question Point zajednički su razvili OCLC (Online Computer Library Center) i Kongresna knjižnica iz Washingtona 2002. godine, a pomoću takvog programskog rješenja omogućeno je jednostavno zaprimanje korisničkih upita mrežnim obrascem te slanje odgovora korisniku e-poštom. ${ }^{27}$ Nacionalna i sveučilišna knjižnica u Zagrebu bila je redovna članica konzorcija od 2005. kao jedina knjižnica iz Hrvatske. ${ }^{28}$ Istodobno se u Knjižnici u sklopu Čitaonica sa slobodnim pristupom građi provodila usluga Pitajte knjižničara - tematsko pretraživanje koja je uključivala pomoć pri složenim i opsežnijim informacijskim upitima za koje su predmetni stručnjaci izrađivali popise relevantne literature na određenu temu za potrebe studenata, znanstveno-nastavnog osoblja i drugih korisnika. Zahtjevi su se zaprimali u prostoru Knjižnice na tiskanim obrascima koje su korisnici ručno popunjavali, nakon čega se provodio informacijski intervju te su se upiti rješavali na licu mjesta. Usluga tematskog pretraživanja uspostavljena je kao mrežna usluga 2012. godine, kada je uslugu Pitajte knjižničara QuestionPoint OCLC-a zamijenila usluga Pitajte knjižničara koja je omogućila slanje zahtjeva mrežnim obrascem, ${ }^{29}$ odnosno obrascima - jedan namijenjen postavljanju općih upita, a drugi slanju zahtjeva za tematsko pretraživanje. Obrazac zahtjeva za tematsko pretraživanje sadržavao je polja za unos osobnih i kontakt podataka, kao i podataka o ustanovi, polja za unos teme pretraživanja i ključnih riječi, stručnog područja prema ponuđenim UDK oznakama, svrhe zahtjeva i načina preuzimanja rezultata (osobno ili e-poštom), a odgovori su se mogli slati korisniku i kroz sustav. ${ }^{30}$ Uspostavljanje usluge na daljinu omogućilo je pružanje relevantnih informacija i pristup izvorima i onim korisnicima koji nisu članovi ili su u nemogućnosti osobno doći u Knjižnicu, pa se tako bilježi velik broj upita iz cijele Hrvatske, ali i inozemstva. Navedeno programsko rješenje i aplikacija Pitajte knjižničara - tematsko pretraživanje uvelike

\footnotetext{
26 Isto, str. 33.

27 Bosančić, B. Nav. dj., str. 80-81.

28 Nacionalna i sveučilišna knjižnica u Zagrebu. Pitajte knjižničara (2005). [citirano 2020-1210]. Dostupno na: http://stari.nsk.hr/DigitalLib.aspx?id=96.

29 Nacionalna i sveučilišna knjižnica u Zagrebu. Usluga Pitajte knjižničara (2010). [citirano 2020-12-10]. Dostupno na: https://www.nsk.hr/usluga-pitajte-knjiznicara/.

30 Vidi. Baj I.; V. Golubović; M. Orešković. Istraživanje korisnika Nacionalne i sveučilišne knjižnice u Zagrebu o novom obliku usluge: tematsko pretraživanje. // Vjesnik bibliotekara Hrvatske 56, 4(2013), 111-112. [citirano 2020-12-08]. Dostupno i na: https://www.hkdrustvo.hr/ vjesnik-bibliotekara-hrvatske/index.php/vbh/article/view/142.
} 
je olakšalo rad i korisnicima i predmetnim stručnjacima, a ista se usluga koristi i danas, u nešto izmijenjenom obliku.

I danas se u sklopu Odjela korisničke službe planiraju, organiziraju i provode opće i stručne informacijske, bibliografske i referalne usluge kako u Knjižnici tako i na daljinu, uključujući odgovaranje na opće upite, tematska i predmetna pretraživanja te bibliometrijske analize. Obavljaju se i djelatnosti pohrane i posudbe građe, kao i međuknjižnična posudba, provodi se edukacija korisnika i stručno vodstvo, izgrađuju zbirke u slobodnom pristupu prema znanstvenim područjima, prvenstveno za potrebe Sveučilišta u Zagrebu, izrađuju se bibliografije, pripremaju izložbe i drugo. Rad Odjela i dalje je organiziran u dvama temeljnim procesima - Informacijski centar na ulaznoj razini kao prva točka susreta korisnika s Knjižnicom te proces Čitaonice i posebne zbirke građe (znanstvene i specijalističke informacije) koji prostorno obuhvaća čitaonice sa slobodnim pristupom građi, uključujući i Čitaonicu periodike i Čitaonicu tekućih hrvatskih i stranih časopisa. Rad na usluzi Pitajte knjižničara provodi se u obama navedenim procesima Odjela. Knjižničari u Informacijskom centru zaduženi su za odgovaranje na upite pristigle mrežnom aplikacijom Pitajte knjižničara - opći upit, odnosno pružaju opće informacije o radu i uslugama knjižnice te usmjeravaju korisnike za daljnje snalaženje, korištenje građe, izvora i slično, dok predmetni stručnjaci u Čitaonicama odgovaraju na upite Pitajte knjižničara - tematsko pretraživanje namijenjene složenim pretraživanjima na određenu temu, prema dodijeljenim područjima i poljima znanosti.

Rad predmetnih stručnjaka obuhvaća i edukaciju korisnika ${ }^{31}$ te izgradnju fonda sveučilišne zbirke. ${ }^{32} \mathrm{U}$ praćenju informacijskih potreba korisnika koje u najvećem broju čine studenti, profesori i istraživači, rad na usluzi Pitajte knjižničara - tematsko pretraživanje uvelike pomaže predmetnim stručnjacima u realizaciji navedenih poslova, aktivnosti i programa rada.

Početkom 2020. godine aplikacija Pitajte knjižničara-tematsko pretraživanje dobila je novi, moderniji dizajn i nove funkcionalnosti. Princip rada ostao je u velikoj mjeri isti, no tijekom godina uočile su se neke poteškoće s prikupljanjem preciznih i točnih informacija u tadašnjim obrascima te se početkom 2020. godine definirao novi. ${ }^{33}$ Najveći problemi s kojima su se predmetni stručnjaci susretali jest

\footnotetext{
31 Osim edukacija pojedinaca u sklopu pružanja usluge tematskog pretraživanja korisnicima koji osobno dođu u Knjižnicu, djelatnici sudjeluju i u provedbi organiziranih individualnih ili grupnih edukacijskih radionica, kao što su radionice o pretraživanju $e$-izvora za korisnike iz sustava znanosti i visokog obrazovanja u sklopu projekta $e$-Izvori i dr.

32 Fond sveučilišne zbirke, koji prema sadržaju i opsegu treba okupljati djela trajne znanstvene, obrazovne, kulturne i umjetničke vrijednosti u skladu s odgojno-obrazovnim potrebama i znanstvenoistraživačkim programima Sveučilišta u Zagrebu izgrađuje se prema: Smjernice za izgradnju sveučilišne zbirke. Zagreb, Nacionalna i sveučilišna knjižnica u Zagrebu, 2017. [interni dokument]. 33 Zahtjev za tematsko pretraživanje. [citirano 2020-02-10]. Dostupno na: https://iks.nsk.hr/tematsko_pretrazivanje/noviZahtjevWebNsk.php
} 
netočno unesena adresa $e$-pošte, što je onemogućilo slanje odgovora, zatim šturo i neodređeno opisivanje teme za koju se traži pretraživanje te odabir stručnog područja, pa su ta polja u obrascu izmijenjena. Sada postoji dodatno polje Potvrda adrese e-pošte, čime su pogrešni unosi e-pošte izbjegnuti, a unos teme pretraživanja proširen je na dva zasebna polja (Naslov teme i Ključne riječi / Opis teme). Zamisao da korisnik odabire stručno područje prema ponuđenim UDK oznakama bila je zamišljena kao pomoć predmetnim stručnjacima da što preciznije smjeste temu u određeno znanstveno područje ili polje, s obzirom na česte interdisciplinarne teme, no u praksi se to pokazalo neupotrebljivim. Budući da korisnici nisu upućeni u knjižnični klasifikacijski sustav, često su dodjeljivali krive ili netočne UDK oznake, ili su se u velikoj mjeri odlučivali za odabir prve ponuđene (0 Znanost i znanje), što je predmetnim stručnjacima dodatno otežalo rad i onemogućilo prikupljanje točne statistike. Sada stručnu oznaku dodjeljuju predmetni stručnjaci. Također se više ne traži broj članske iskaznice, što je i prije bilo neobavezno polje, jer se usluga pruža i nečlanovima Knjižnice. To polje zbunjivalo je korisnike te su često upisivali podatke s tuđe iskaznice i slično. Sada se od korisnika traži samo podatak jesu li članovi Knjižnice ili ne. Uvedena su i neka nova polja, primjerice status korisnika (maturant, student, znanstveno-nastavno osoblje, znanstveni i kulturni radnik, građanin), što uvjetuje daljnje otvaranje novih obveznih polja u obrascu (podaci o ustanovi, studiju/odjelu/smjeru), a novost je i mogućnost unosa napomene za knjižničara, gdje korisnici mogu dodatno opisati svoju temu ili unijeti napomene o preferiranoj vrsti građe i izvora, jezika i slično. Potonje se pokazalo iznimno korisnim i često se koristi. Odgovori se korisnicima šalju isključivo $e$-poštom, što se pokazalo uspješnijim načinom komunikacije od slanja odgovora kroz sustav. Ostale se novosti odnose na redizajn sučelja i nove administratorske funkcionalnosti koje su olakšale rad u aplikaciji (pristup i pretraživanje zajedničke Arhive odgovora, uvid u vlastite statističke podatke).

Usluga tematskog pretraživanja koristi se učestalo, a godišnje pristiže i do tri tisuće zahtjeva. Najviše zahtjeva pristiže od studenata, u svrhu pisanja diplomskih, seminarskih i drugih radova. Iz dosadašnjih statistika vidljivo je da najveći broj zahtjeva pristiže iz područja društvenih znanosti, najvećim dijelom iz ekonomije, prava, politike, obrazovanja i sociologije, zatim primijenjenih znanosti, područja biomedicine i zdravstva te tehničkih i biotehničkih znanosti (agronomija, šumarstvo, promet).

O usluzi je već provedeno nekoliko različitih istraživanja. Od 2002. do 2003. provedena je analiza 1000 obrađenih zahtjeva za tematsko pretraživanje iz ekonomskih, tehničkih, tehnoloških i informacijskih znanosti, koja je poslužila kao podloga za razvoj zbirki te kao pokazatelj učestalosti korištenja baza podataka i smjernica za njihovu nabavu. ${ }^{34}$ Godine 2010. provedena je kvantitativna analiza

34 Vidi. Bačić, M.; Z. Majstorović. Nacionalna i sveučilišna knjižnica: stanje i perspektive tematskih pretraživanja za korisnike. // 7. Seminar Arhivi, knjižnice, muzeji: mogućnost suradnje u 
1547 obrađenih zahtjeva jednog predmetnog stručnjaka tijekom jedne godine za određena polja društveno-humanističkih znanosti i umjetničko područje te je dan osvrt na informacijske potrebe i nužnost edukacije korisnika. ${ }^{35}$ Godine 2013. na uzorku od 400 ispitanika provedeno je anketno istraživanje zadovoljstva korisnika novim, mrežnim oblikom usluge Pitajte knjižničara-tematsko pretraživanje te se zaključuje kako je prijelaz s tiskanog na mrežni obrazac omogućio jednostavnije i brže postavljanje, kao i obradu zahtjeva, čime je povećano zadovoljstvo korisnika. Ispitanici su izrazili zadovoljstvo i kvalitetom usluge i komunikacijom s predmetnim stručnjacima. ${ }^{36}$

\section{Istraživanje: zadovoljstvo korisnika uslugom Pitajte knjižničara - tematsko pretraživanje tijekom pandemije koronavirusa}

\section{1. Uvod}

Za potrebe analize statističkih pokazatelja o korištenju usluge Pitajte knjižničara-tematsko pretraživanje te istraživanja korisnika usluge u obzir se uzelo razdoblje u kojem su se provodile mjere izolacije koje su vrijedile i za djelatnike i za korisnike, od 20. ožujka do 8. svibnja 2020. Prema podacima iz mrežne aplikacije, u navedenom je razdoblju pristiglo ukupno 289 zahtjeva od 236 korisnika, što znači da je 35 korisnika poslalo zahtjev više od jedanput. Najveći broj zahtjeva pristigao je s hrvatskih sveučilišta $(205 ; 70,93 \%)$, a slijede ih veleučilišta $(50 ; 17,3$ $\%)$. Znatan broj zahtjeva pristigao je iz stranih visokih učilišta $(14 ; 4,84 \%)$, nešto manji broj iz srednjih škola $(6 ; 2,07 \%)$ te visokih učilišta i škola $(5 ; 1,73 \%)$, dok su neki korisnici odabrali kategoriju Ostalo $(7 ; 2,42 \%)$. Više od polovine zahtjeva pristiglo je iz područja društvenih znanosti $(113 ; 39,1 \%)$, i to najviše iz polja ekonomije (37), pedagogije (21) i prava (19), zatim primijenjenih znanosti $(87 ; 30,1$ $\%$ ), među kojima prevladavaju medicina (27), sestrinstvo (13) i agronomija (8). Preostali broj zahtjeva $(89 ; 40 \%)$ odnosio se na različite teme raspoređene prema ostalim stručnim područjima. Usluga se koristila u najvećem broju u svrhu pisanja seminarskih $(92,31,83 \%)$, diplomskih $(88,30,45 \%)$ i završnih radova studenata (74, 25,6 \%), a manji broj zahtjeva u ostale svrhe (tablica 1).

okruženju globalne informacijske infrastrukture: zbornik radova / ur. Tinka Katić. Zagreb: Hrvatsko knjižničarsko društvo, 2004. Str. 47-52.

35 Vidi. Grečl, B. Tematska pretraživanja u Nacionalnoj i sveučilišnoj knjižnici u Zagrebu u središnjoj službi čitaonica. // Knjižnice: kamo i kako dalje?: pohrana i zaštita knjižnične građe: profesija „knjižničar“??? : usluge i korisnici: zbornik radova / ur. Alisa Martek i Elizabeta Rybak Budić. Zagreb: Hrvatsko knjižničarsko društvo, 2013. Str. 348-357.

36 Baj I.; V. Golubović; M. Orešković. Nav. dj., str. 107-128. 
Tablica 1. Broj pristiglih zahtjeva za tematsko pretraživanje prema svrsi $(\mathrm{N}=289)$

\begin{tabular}{|l|c|c|}
\hline Svrha zahtjeva & Broj zahtjeva & $\mathbf{\%}$ \\
\hline Seminarski rad & 92 & 31,83 \\
\hline Diplomski rad & 88 & 30,45 \\
\hline Završni rad (preddiplomski studij) & 74 & 25,6 \\
\hline Istraživanje/rad na projektu/studija & 12 & 4,15 \\
\hline Završni rad učenika & 9 & 3,11 \\
\hline Ostalo & 6 & 2,07 \\
\hline Poslijediplomski specijalistički rad & 5 & 1,73 \\
\hline Doktorska disertacija & 3 & 1,03 \\
\hline
\end{tabular}

\subsection{Cilj i svrha istraživanja korisnika usluge Pitajte knjižničara - te- matsko pretraživanje}

Cilj istraživanja bio je ispitati zadovoljstvo korisnika pruženom uslugom $P i$ tajte knjižničara - tematsko pretraživanje tijekom fizičkog zatvaranja Knjižnice i uspostave rada djelatnika od kuće, kada su na snazi bile mjere izolacije radi suzbijanja širenja bolesti COVID-19. Svrha istraživanja bila je vrednovati uslugu, odnosno utvrditi jesu li i u kojoj mjeri predmetni stručnjaci uspješno odgovorili na potrebe korisnika, pogotovo s obzirom na zahtjeve za što većim brojem izvora u digitalnom obliku, kao i utvrditi postoji li značajnija razlika u pružanju usluge s obzirom na promijenjene uvjete rada uzrokovane širenjem pandemije koronavirusa i pružanje usluge isključivo na daljinu.

\subsection{Metoda istraživanja}

Za provedbu istraživanja korištena je metoda ankete, za čije je provođenje izrađen mrežni anketni upitnik (Google forms) od 10 pitanja: 9 zatvorenih i 1 pitanje otvorenog tipa (prilog 1). Poziv za ispunjavanjem anketnog upitnika poslan je $e$-poštom na adrese korisnika koji su uslugu Pitajte knjižničara - tematsko pretraživanje koristili od 20. ožujka do 8. svibnja. Istraživanje je provedeno tijekom ljeta, od 4. do 31. srpnja, čemu možemo pripisati slabiji odaziv - na anketu se od 236 korisnika odazvalo tek 50 ispitanika (21\%). 


\subsection{Rezultati i rasprava}

Na prvo pitanje: Jeste li član Knjižnice?, samo je 20 (40\%) od 50 ispitanika odgovorilo potvrdno, što znači da su uslugu Pitajte knjižničara - tematsko pretraživanje tijekom izvanrednih uvjeta rada u većem broju koristili nečlanovi Knjižnice (30; $60 \%$ ). Kao što je prethodno u radu spomenuto, usluga se i u redovnim uvjetima pruža svima bez obzira na članstvo, a činjenicu da je u istraživanju velik broj nečlanova koristio uslugu možemo povezati i sa znatnim brojem zahtjeva studenata visokih učilišta izvan Zagreba, kao i iz inozemstva.

Na drugo pitanje Jeste li koristili uslugu „Pitajte knjižničara - tematsko pretraživanje " i prije pandemije koronavirusa i zatvaranja Knjižnice za korisnike? 39 (78 \%) ispitanika odgovorilo je potvrdno, odnosno da su uslugu koristili i tijekom redovnih radnih uvjeta Knjižnice, što potvrđuje kako postoje „stalni““ korisnici koji su navikli koristiti uslugu, dok je 11 (22\%) ispitanika odgovorilo da nisu koristili uslugu prije pandemije.

U trećem pitanju Što je utjecalo na Vašu odluku da koristite uslugu „Pitajte knjižničara - tematsko pretraživanje" tijekom pandemije koronavirusa? ispitanicima je bila ponuđena mogućnost višestrukog odabira odgovora, kao i mogućnost samostalnog upisivanja odgovora (tablica 2). Najveći broj ispitanika, njih 29 (58 $\%$ ), odgovorio je kako su na odluku utjecala prijašnja pozitivna iskustva, što se može povezati s rezultatima iz prethodnog pitanja, kojima je utvrđeno da je većina ispitanika uslugu koristila i tijekom redovnih uvjeta rada Knjižnice, dok je 28 (56 $\%$ ) ispitanika navelo preporuku druge osobe. Odluku o korištenju usluge 22 (44 $\%$ ) ispitanika donijela su zbog nemogućnosti osobnog dolaska u prostor Knjižnice tijekom izvanrednih uvjeta rada, što se može povezati s činjenicom da velik broj korisnika, unatoč postojanju mrežne inačice usluge, u redovnim uvjetima rada radije bira osobni dolazak u Knjižnicu, samostalno pretraživanje, korištenje tiskane građe, komunikaciju s predmetnim stručnjakom i sl. Čak 16 (32 \%) ispitanika navelo je kao odgovor nepostojanje takve usluge u knjižnici njihovog matičnog fakulteta/ustanove, a njih 8 (16\%) nemogućnost korištenja takve usluge zbog zatvaranja knjižnice matičnog fakulteta ili ustanove. Nedostatak vremena za samostalno pretraživanje razlog je kod 10 (20\%), a nedostatak znanja o dostupnim izvorima i samostalnom pretraživanju kod 19 (38 \%) ispitanika, dok je 11 (22\%) ispitanika kao razlog navelo nepovjerenje u vlastite rezultate pretraživanja. Jedan ispitanik samostalno je dopisao razlog - Nedovoljno znanja o specijalnosti na platformama servera sa člancima i nedovoljno vremena. 
Tablica 2. Razlozi zbog kojih su se ispitanici odlučili na korištenje usluge Pitajte knjižničara - tematsko pretraživanje tijekom izvanrednih uvjeta rada Knjižnice $(\mathrm{N}=50)$

\begin{tabular}{|l|r|r|}
\hline & $\begin{array}{c}\text { Broj } \\
\text { odgovora }\end{array}$ & \multicolumn{1}{c|}{ \% } \\
\hline Dosadašnja pozitivna iskustva s korištenjem usluge & 29 & 58 \\
\hline Preporuka druge osobe & 28 & 56 \\
\hline $\begin{array}{l}\text { Nemogućnost osobnog dolaska u prostor NSK zbog } \\
\text { izvanrednih uvjeta rada }\end{array}$ & 22 & 44 \\
\hline $\begin{array}{l}\text { Nepostojanje takve usluge u knjižnici matičnog fakulteta/ } \\
\text { ustanove }\end{array}$ & 16 & 32 \\
\hline $\begin{array}{l}\text { Nemogućnost korištenja takve usluge zbog zatvaranja } \\
\text { knjižnice matičnog fakulteta/ustanove }\end{array}$ & 8 & 16 \\
\hline Nedostatak vremena za samostalno pretraživanje & 19 & 38 \\
\hline $\begin{array}{l}\text { Nedostatak znanja o dostupnim izvorima i samostalnom } \\
\text { pretraživanju }\end{array}$ & 11 & 22 \\
\hline Nepovjerenje u vlastite rezultate pretraživanja & 1 & 2 \\
\hline $\begin{array}{l}\text { *Drugo: Nedovoljno znanja o specijalnosti na platformama } \\
\text { servera sa člancima i nedovoljno vremena }\end{array}$ & & \\
\hline
\end{tabular}

Četvrto pitanje odnosilo se na ocjenjivanje ispitanika zadovoljstvom usluge: Na ljestvici od 1 do 5, od kojih 1 znači ,iznimno nezadovoljan“, a 5 ,iznimno zadovoljan “, ocijenite Vaše zadovoljstvo uslugom „Pitajte knjižničara-tematsko pretraživanje" s obzirom na izvanredne uvjete rada. Ponuđeno je pet odgovora prema Likertovoj ljestvici: (1) iznimno nezadovoljan, (2) nezadovoljan, (3) niti nezadovoljan, niti zadovoljan, (4) zadovoljan i (5) iznimno zadovoljan, a rezultati su prikazani u tablici 3.

Tablica 3. Zadovoljstvo uslugom s obzirom na izvanredne uvjete rada Knjižnice $(\mathrm{N}=50)$

\begin{tabular}{|l|c|c|c|c|c|}
\hline & (1) & (2) & (3) & (4) & (5) \\
\hline Kvaliteta sadržaja preporučene literature i izvora & & & 2 & 19 & 29 \\
\hline Broj preporučene literature i izvora & & & 3 & 18 & 29 \\
\hline Dostupnost sadržaja preporučene literature i izvora & & 5 & 6 & 18 & 21 \\
\hline Brzina odgovora & & & & 8 & 42 \\
\hline Dodatne informacije uz rezultate pretraživanja & 1 & & 7 & 17 & 25 \\
\hline $\begin{array}{l}\text { Komunikacija s knjižničarom (predmetnim } \\
\text { stručnjakom) }\end{array}$ & & & 1 & 8 & 41 \\
\hline
\end{tabular}


Rezultati pokazuju kako su ispitanici zadovoljni pruženom uslugom, s obzirom na to da je najveći broj ispitanika sve ponuđene segmente usluge ocijenio najvišom ocjenom. Kvalitetom sadržaja preporučene literature i izvora iznimno je zadovoljno 29 (58 \%) ispitanika, zadovoljno 19 (38 \%), a kao niti nezadovoljan, niti zadovoljan izjasnila su se $2(4 \%)$ ispitanika. Brojem jedinica preporučene literature i izvora iznimno je zadovoljno 29 (58 \%) ispitanika, zadovoljno 18 (36 $\%$ ), a niti nezadovoljno, niti zadovoljno 3 (6 \%) ispitanika. Što se tiče dostupnosti sadržaja preporučene literature i izvora, 21 (42\%) ispitanik izjasnio se kao iznimno zadovoljan, 18 (36 \%) kao zadovoljan, 6 (12\%) kao niti zadovoljan niti nezadovoljan, a 5 (10\%) kao nezadovoljan. Rezultati su očekivani s obzirom na to da su korisnici ovisili o dostupnosti i pristupu građe u otvorenom pristupu, na što predmetni stručnjaci nisu imali previše utjecaja. Uza sav trud i napor u pronalaženju cjelovitih tekstova, temeljna literatura koja se tražila iz pojedinih polja društvenih i humanističkih znanosti (npr. pravo, književnost, povijest, umjetnost $i$ sl.) još uvijek je zastupljenija kao tiskana građa (udžbenici, priručnici) te su glavni izvor informacija u većini slučajeva knjige, a u manjem broju članci. Ta je literatura i inače slabije zastupljena u otvorenom pristupu, pa i to može biti razlogom nezadovoljstva ispitanika. Brzinom odgovora iznimno je zadovoljno 42 (84 \%) ispitanika, a zadovoljno 8 (16 \%). Činjenica je da su predmetni stručnjaci radeći od kuće imali više vremena posvetiti se tematskim pretraživanjima jer su bili rasterećeni od dijela poslova za koje je potreban rad u prostoru Knjižnice, čemu se može pripisati iznimno zadovoljstvo brzinom odgovaranja na pojedine upite. Dodatnim informacijama uz rezultate pretraživanja ${ }^{37}$ iznimno je bilo zadovoljno 25 (50\%) ispitanika, zadovoljno 17 (34\%), a niti nezadovoljno, niti zadovoljno 7 (14\%) ispitanika, dok je 1 (2\%) ispitanik izrazio iznimno nezadovoljstvo. Budući da je uobičajeno da se s korisnicima često komunicira i telefonski ili u prostoru Knjižnice, a da je sva komunikacija u novonastalim uvjetima bila omogućena isključivo $e$-poštom, tražilo se od ispitanika da izraze zadovoljstvo i tim segmentom usluge. Komunikacijom s predmetnim stručnjakom iznimno je zadovoljan 41 (82 $\%$ ) ispitanik, zadovoljno 8 (16\%), a niti nezadovoljan niti zadovoljan jest 1 (2\%) ispitanik.

Na peto pitanje Na ljestvici od 1 do 5, od kojih 1 znači ,,nezadovoljavajuća “, a 5 ,,izvrsna“, ocijenite kvalitetu usluge „,Pitajte knjižničara - tematsko pretraživanje" tijekom redovnog i izvanrednog rada Knjižnice, ispitanici su ovako ocijenili kvalitetu usluge tijekom redovnog rada Knjižnice: iznimno zadovoljan (17; 34 \%), zadovoljan (14; $28 \%$ ), niti nezadovoljan niti zadovoljan (5; $10 \%$ ), nezadovoljan (2; $4 \%$ ). Kvaliteta usluge tijekom izvanrednog rada Knjižnice ocijenjena je na sljedeći način: iznimno zadovoljan (23; $46 \%$ ), zadovoljan (11; $22 \%)$, niti nezadovoljan niti zadovoljan $(3 ; 6 \%)$, nezadovoljan $(2 ; 4 \%)$ Na pitanje o usporedbi

37 Informacije o radu Knjižnice, uvjetima i načinu korištenja građe, druge usluge na daljinu koje Knjižnica nudi i sl. 
kvalitete mogli su odgovoriti samo oni ispitanici koji su uslugu koristili i tijekom redovnih uvjeta rada Knjižnice, njih 38 (76 \%). Prema dobivenim rezultatima, veći broj ispitanika iznimno je zadovoljan kvalitetom usluge tijekom izvanrednog rada Knjižnice, što možemo pripisati dodatnom trudu predmetnih stručnjaka za pronalaženjem cjelovitih tekstova, a koji u redovnom radnom vremenu Knjižnice nisu toliko u fokusu zbog dostupnosti i relevantnosti tiskane građe iz fonda Knjižnice (ovisno o temi i području).

$\mathrm{Na}$ šesto pitanje Jeste li naknadno samostalno pretraživali preporučene e-izvo$r e$ ? čak $46(92 \%)$ ispitanika odgovorilo je potvrdno, odnosno samo 4 (8\%) ispitanika nije samostalno pretraživalo $e$-izvore.

Sedmo pitanje Ako ste na prethodno pitanje odgovorili s , DA“, označite e-izvore koje ste pretraživali bilo je postavljeno kao nastavak na prethodno, a rezultati pokazuju kako je najveći postotak ispitanika $(41 ; 89,1 \%)$ naknadno pretraživao Portal hrvatskih znanstvenih i stručnih časopisa RH (Hrčak), zatim Google Znalac (30; 65,2 \%), digitalne repozitorije (21;45,7 \%), Portal elektroničkih izvora za hrvatsku akademsku i znanstvenu zajednicu $(18 ; 39,1 \%)$ te mrežne kataloge knjižnica $(17 ; 37 \%)$. Za hrvatsku akademsku i znanstvenu zajednicu od 19. ožujka do 8. svibnja bilo je otvoreno 14 međunarodnih baza znanstvenih radova u probnom pristupu, uključujući časopise, $e$-udžbenike i $e$-knjige, ${ }^{38}$ koji su korisnicima bili dostupni udaljenim pristupom na Portalu elektroničkih izvora za hrvatsku akademsku i znanstvenu zajednicu. Nacionalna i sveučilišna knjižnica u Zagrebu, kao i mnoge druge visokoškolske knjižnice redovno su izvještavale o tome na svojim mrežnim stranicama i društvenim mrežama, no rezultati anketnog istraživanja pokazuju da se manji broj ispitanika služio navedenim izvorima.

Na osmo pitanje Biste li ponovno koristili uslugu „Pitajte knjižničara-tematsko pretraživanje“? svih 50 ispitanika odgovorilo je potvrdno (100\%), a jednaki odgovori bili su i na devetom pitanju Biste li preporučili uslugu „Pitajte knjižničara - tematsko pretraživanje" nekom drugom?

Posljednje, deseto pitanje Ako imate komentar, sugestiju i/ili prijedlog o usluzi „Pitajte knjižničara - tematsko pretraživanje“ "bilo je otvorenog tipa, a svoje je odgovore upisalo 9 ispitanika. Komentari su sadržavali uglavnom pohvale i zadovoljstvo brzinom i kvalitetom usluge, a vrijedne su i pristigle sugestije o tome da se duži popisi literature numeriraju i sastavljaju u nešto „čitljivijem formatu“ radi lakšeg snalaženja.

38 Objave o probnim pristupima dostupni su u rubrici Novosti na Portalu elektroničkih izvora za hrvatsku akademsku i znanstvenu zajednicu. [citirano 2020-12-12]. Dostupno na: http://baze. nsk.hr/novosti/. 


\section{Zaključak}

U radu su predstavljeni rezultati provedenog istraživanja zadovoljstva korisnika mrežnom uslugom Pitajte knjižničara - tematsko pretraživanje koja je tijekom pandemije koronavirusa i izvanrednih uvjeta rada Knjižnice neprekidno bila dostupna korisnicima i široj javnosti. Dobiveni rezultati pokazuju kako je usluga Pitajte knjižničara - tematsko pretraživanje uspješno odgovorila na zahtjeve korisnika te održala istu razinu kvalitete unatoč promijenjenim radnim uvjetima. Uslugu su koristili i članovi i nečlanovi Knjižnice, a utvrdilo se i da je većina ispitanika uslugu koristila i prije izvanrednih uvjeta rada te da je upravo prethodno pozitivno iskustvo kod najvećeg broja ispitanika bio razlog što su uslugu koristili i tijekom pandemije. Najbolji pokazatelj uspješnosti pružanja usluge proizlazi iz visoko ocijenjenih segmenata kao što su kvaliteta, broj i dostupnost sadržaja preporučene literature i izvora, brzina odgovora, dodatne informacije u kojima im se predlažu informacijski izvori za samostalno korištenje te komunikacija s predmetnim stručnjakom, koje su najveći odraz zadovoljstva ispitanika. Iz rezultata je također vidljivo da se kvaliteta usluge tijekom izvanrednog rada Knjižnice nije smanjila, ispitanici su čak svoje iznimno zadovoljstvo uslugom u većoj mjeri iskazali za kvalitetu usluge u izvanrednom nego redovnom radu Knjižnice, što se može povezati s činjenicom da su rezultati pretraživanja uglavnom bili sadržaji u otvorenom pristupu, kao i time što su djelatnici na radu od kuće bili rasterećeni od nekih redovnih poslova te su korisnici odgovore dobivali u vrlo kratkom roku. Pokazalo se i da je većina ispitanika naknadno samostalno pretraživala preporučene $e$-izvore (Hrčak, Google Znalac i dr.). Svi ispitanici odgovorili su da bi uslugu koristili ponovno, kao i da bi uslugu preporučili nekom drugom, a neki su iznijeli i pozitivne komentare o usluzi općenito. Unatoč malom broju ispitanika, rezultati istraživanja ukazuju na to da je usluga Pitajte knjižničara-tematsko pretraživanje funkcionalna kao usluga na daljinu, a povratne informacije korisnika o zadovoljstvu načinom pružanja usluge i radu predmetnih stručnjaka vrijedne su smjernice za daljnje planiranje, razvoj i unaprjeđivanje.

\section{LITERATURA}

Asif, M.; K. K. Singh. Trends, opportunities and scope of libraries during Covid-19 pandemic. // IP Indian Journal of Library Science and Information Technology 5, 1(2020), 24-27. DOI: https://10.18231/j.ijlsit.2020.005.

Bačić, M.; Z. Majstorović. Nacionalna i sveučilišna knjižnica: stanje i perspektive tematskih pretraživanja za korisnike. // 7. Seminar Arhivi, knjižnice, muzeji: mogućnost suradnje u okruženju globalne informacijske infrastrukture: zbornik radova / ur. Tinka Katić. Zagreb: Hrvatsko knjižničarsko društvo, 2004. Str. 47-52. 
Baj I.; V. Golubović; M. Orešković. Istraživanje korisnika Nacionalne i sveučilišne knjižnice u Zagrebu o novom obliku usluge: tematsko pretraživanje. // Vjesnik bibliotekara Hrvatske 56, 4(2013), 111-112. [citirano 2020-12-10]. Dostupno i na: https:// www.hkdrustvo.hr/vjesnik-bibliotekara-hrvatske/index.php/vbh/article/view/142.

Bakker, T. Virtual reference services: connecting users with experts and supporting the development of skills. // LIBER Quarterly 12, 2-3(2002), 124-137. DOI: http://doi. org/10.18352/lq.7676.

Bosančić B. Online referentne usluge: pregled razvoja u teoriji i praksi. // Vjesnik bibliotekara Hrvatske 53, 1(2010), 64-86. [citirano 2020-12-08]. Dostupno i na: https:// www.hkdrustvo.hr/vjesnik-bibliotekara-hrvatske/index.php/vbh/article/view/446.

Breeding, M. Providing virtual reference service. // Information Today 18, 4(2001), 4243.

Coffman, S. Going live: starting \& running a virtual reference service. Chicago: American Library Association, 2003.

Gómez-Cruz, M. E. Electronic reference services: a quality and satisfaction evaluation. // Reference Services Review 47, 2(2019), 118-133. DOI: https://oi.org/10.1108/ RSR-07-2018-0057.

Grečl, B. Tematska pretraživanja u Nacionalnoj i sveučilišnoj knjižnici u Zagrebu u središnjoj službi čitaonica. // Knjižnice: kamo i kako dalje?: pohrana i zaštita knjižnične građe: profesija „knjižničar"??? : usluge i korisnici: zbornik radova / ur. Alisa Martek i Elizabeta Rybak Budić. Zagreb: Hrvatsko knjižničarsko društvo, 2013. Str. 348-357.

Guo, Y.; Z. Yang; Z. Yang; Y. Q. Liu; A. Bielefield; G. Tharp. The provision of patron services in Chinese academic libraries responding to the COVID-19 pandemic. // Library Hi Tech 38, 4(2020). Publication date: 21 July 2020. DOI: https://doi. org/10.1108/LHT-04-2020-0098.

Komisija za informacijske tehnologije Hrvatskog knjižničarskog društva. Knjižnične usluge na daljinu - Remote Library Services. [citirano 2020-02-12]. Dostupno na: https://padlet.com/hkdrustvo/knjiznicne_usluge_na_daljinu.

Lauer, J. D. ; S. McKenzie. Bad moon rising: a candid examination of digital reference and what it means to the profession. // Digital reference services / ed. B. Katz. New York: The Haworth Information Press, 2003. Str. 45-56.

Mihalić, M. Međunarodna kooperativna informacijska usluga QuestionPoint - pitajte knjižničara u Nacionalnoj i sveučilišnoj knjižnici u Zagrebu. // 2. međunarodna konferencija BAM 2008 Evropske smjernice za saradnju biblioteka, arhiva i muzeja: Promocija usluga za korisnike: zbornik radova / ur. Lejla Kodrić, Nataša Milićević, Biserka Sabljaković. Sarajevo: Asocijacija informacijskih stručnjaka - bibliotekara, arhivista i muzeologa; Ekonomski fakultet, 2010. Str. 32-44. [citirano 2020-12-10]. Dostupno na: http://www.bam.ba/images/stories/Zbornici/bam_zbornik_2008_online.pdf. 
Nacionalna i sveučilišna knjižnica u Zagrebu. Obavijest korisnicima o zatvaranju Knjižnice u skladu s mjerama suzbijanja širenja bolesti COVID-19. 19. ožujka 2020., 7.30. [citirano 2021-02-12]. Dostupno na: https://www.nsk.hr/obavijest-korisnicima-o-zatvaranju-knjiznice-u-skladu-s-mjerama-suzbijanja-sirenja-bolesti-covid-19-19-ozujka-2020-7-30/.

Nacionalna i sveučilišna knjižnica u Zagrebu. Obavijest o otvaranju čitaonica Knjižnice prema ograničenom sustavu rada. 21. svibnja 2020. [citirano:2021-03-02]. Dostupno na: https://www.nsk.hr/obavijest-o-otvaranju-citaonica-knjiznice-prema-ogranicenom-sustavu-rada-21-svibnja-2020/.

Nacionalna i sveučilišna knjižnica u Zagrebu. Odluka o organizaciji rada, rasporedu rada i radnog vremena tijekom trajanja epidemije bolesti COVID 19 uzrokovane virusom SARS-CoV-2. 20. ožujka 2020. [citirano 2021-02-12]. Dostupno na: https:// www.nsk.hr/wp-content/uploads/2020/04/Odluka-o-organizaciji-rada-COVID-19. pdf.

Nacionalna i sveučilišna knjižnica u Zagrebu. Pitajte knjižničara (2005). [citirano 202012-10]. Dostupno na: http://stari.nsk.hr/DigitalLib.aspx?id=96.

Nacionalna i sveučilišna knjižnica u Zagrebu. Podsjetnik o trenutačno dostupnim uslugama Nacionalne i sveučilišne knjižnice u Zagrebu. 25.ožujka 2020. [citirano 202102-12]. Dostupno na: https://www.nsk.hr/podsjetnik-o-trenutno-dostupnim-uslugama-nacionalne-i-sveucilisne-knjiznice-u-zagrebu/.

Nacionalna i sveučilišna knjižnica u Zagrebu. Središnja informacijska služba (2005). [citirano 2020-12-10]. Dostupno na: http://stari.nsk.hr/Service.aspx?id=48.

Nacionalna i sveučilišna knjižnica u Zagrebu. Usluga Pitajte knjižničara (2010). [citirano 2020-12-10]. Dostupno na: https://www.nsk.hr/usluga-pitajte-knjiznicara/.

New directions in reference / ed. Byron Andreson and Paul T. Webb. Binghamton: The Haworth Information Press, 2006.

Okonoko, V. N.; M. A. Abba, M. A.; A. E. Arinola, users' expectation of library services and resources in the COVID 19 pandemic era: a comparative study of two academic libraries in Nigeria. // Library Progress (International) 40, 2(2020), 236-246. DOI: http://dx.doi.org/10.5958/2320-317X.2020.00027.6.

Oluwabiyi, M. O. Digital reference services: an overview. // Information Impact: Journal of Information and Knowledge Management 8, 1(2017), 66-75. DOI: https:// dx.doi.org/10.4314/iijikm.v8i1.8.

Oyelude, A. Libraries, librarians, archives, museums and the COVID-19 pandemic. // Library Hi Tech News 9, 5/6(2020), 5-6. DOI: https://doi.org/10.1108/LHTN-052020-0049.

Portal elektroničkih izvora za hrvatsku akademsku i znanstvenu zajednicu. [citirano 2020-12-10]. Dostupno na: http://baze.nsk.hr/. 
Sanders, L. The Reality of reference: responsibilities and competencies for current reference librarians. // Public Services Quarterly 8, 2(2012), 114-135. DOI: https://doi. org/10.1080/15228959.2012.662074.

Sečić, D. Informacijska služba u knjižnici. Lokve: Benja, 1995.

Sloan, B. Service perspectives for the digital library remote reference services. // Library Trends 47, 1 (1998), 117-143. [citirano 2020-02-12]. Dostupno na: http://hdl. handle.net/2142/8200.

Smjernice za izgradnju sveučilišne zbirke. Zagreb, Nacionalna i sveučilišna knjižnica u Zagrebu, 2017. [interni dokument].

Stephen, G. Chat metric for li(fe)brary at home whatsapp forum with user satisfaction of NIELIT - Itanagar Library, Arunachal Pradesh. // Library Philosophy and Practice (e-journal), 4818 (2021). [citirano 2020-02-10]. Dostupno na: https://digitalcommons.unl.edu/libphilprac/4818/.

VandeCreek, L. M. E-mail reference evaluation: using the results of a satisfaction survey. // The Reference Librarian 45, 93(2006), 99-108. DOI: https://doi.org/10.1300/ J120v45n93_08.

Walsh, B.; H. Rana. Continuity of academic library services during the pandemic: The University of Toronto Libraries' response. // Journal of Scholarly Publishing 51, 4(2020), 237-245. DOI: https://doi.org/10.3138/jsp.51.4.04.

Zahtjev za tematsko pretraživanje. [citirano 2020-02-10]. Dostupno na: https://iks.nsk. hr/tematsko_pretrazivanje/noviZahtjevWebNsk.php. 


\section{Prilog 1. \\ Anketni upitnik}

1. Jeste li član Nacionalne i sveučilišne knjižnice u Zagrebu?*

o Da

o $\mathrm{Ne}$

2. Jeste li koristili uslugu Pitajte knjižničara - tematsko pretraživanje i prije pandemije koronavirusa i zatvaranja Knjižnice za korisnike?*
o Da
o $\mathrm{Ne}$

3. Što je utjecalo na Vašu odluku da koristite uslugu Pitajte knjižničara - tematsko pretraživanje tijekom pandemije koronavirusa? (moguće je označiti više odgovora)*

- Dosadašnja pozitivna iskustva s korištenjem usluge

- Preporuka druge osobe

- Nemogućnost osobnog dolaska u prostor NSK zbog izvanrednih uvjeta rada

- Nepostojanje takve usluge u knjižnici matičnog fakulteta/ustanove

- Nemogućnost korištenja takve usluge zbog zatvaranja knjižnice matičnog fakulteta/ustanove

- Nedostatak vremena za samostalno pretraživanje

- Nedostatak znanja o dostupnim izvorima i samostalnom pretraživanju

- Nepovjerenje u vlastite rezultate pretraživanja

- Ostalo

4. Na ljestvici od 1 do 5, od kojih 1 znači „iznimno nezadovoljan“, a 5 „iznimno zadovoljan“, ocijenite Vaše zadovoljstvo uslugom Pitajte knjižničara - tematsko pretraživanje s obzirom na izvanredne uvjete rada:*

o Kvaliteta sadržaja preporučene literature i izvora

o Broj preporučene literature i izvora

o Dostupnost sadržaja preporučene literature i izvora

o Brzina odgovora

o Dodatne informacije uz rezultate pretraživanja (informacije o radu Knjižnice, uvjetima i načinu korištenja građe i sl.)

o Komunikacija s knjižničarom (predmetnim stručnjakom) 
5. Na ljestvici od 1 do 5, od kojih 1 znači „nezadovoljavajuća“, a 5 ,izvrsna“, ocijenite kvalitetu usluge Pitajte knjižničara - tematsko pretraživanje tijekom redovnog i izvanrednog rada Knjižnice (ako ste uslugu koristili prvi put tijekom pandemije, preskočite ovo pitanje)

o Kvaliteta usluge tijekom redovnog rada Knjižnice

o Kvaliteta usluge tijekom izvanrednog rada Knjižnice

6. Jeste li naknadno samostalno pretraživali preporučene $e$-izvore?*

o Da

o $\mathrm{Ne}$

7. Ako ste na prethodno pitanje odgovorili s „DA“, označite $e$-izvore koje ste pretraživali: (moguće je označiti više odgovora)

- Mrežni katalozi knjižnica

- Google Znalac

- Portal hrvatskih znanstvenih i stručnih časopisa RH (Hrčak)

- Digitalni repozitoriji ustanova iz sustava znanosti i visokog obrazovanja

- Baze znanstvenih radova na Portalu elektroničkih izvora za hrvatsku akademsku i znanstvenu zajednicu

8. Biste li ponovno koristili uslugu Pitajte knjižničara-tematsko pretraživanje?*

$0 \mathrm{Da}$

o $\mathrm{Ne}$

o Ne znam

9. Biste li preporučili uslugu Pitajte knjižničara - tematsko pretraživanje nekom drugom?*

$0 \mathrm{Da}$

o $\mathrm{Ne}$

o Ne znam

10. Ako imate komentar, sugestiju i/ili prijedlog o usluzi Pitajte knjižničara - tematsko pretraživanje, molimo Vas da ih navedete: 